\title{
Assessment of endophytic fungal isolates for its Antibiofilm activity on Pseudomonas aeruginosa
}

\author{
Ashok Y. Dawande*11, Neha D. Gajbhiye ${ }^{2}$, Vijay N. Charde ${ }^{3}$, Yogesh S. Banginwar ${ }^{4}$ \\ ${ }^{1,2,3}$ Department of Microbiology, Taywade College, Koradi, Nagpur, India \\ ${ }^{4}$ Department of Microbiology, Arts and Science College, Pulgaon, Wardha, India \\ Corresponding Author: ashokdawande@gmail.com
}

Available online at: www.isroset.org

Received: 29/May/2019, Accepted: 19/Jun/2019, Online: 30/Jun/2019

\begin{abstract}
The present study reports assessment of the antibiofilm activity of endophytic fungi on quorum sensing controlled biofilm formation in Pseudomonas aeruginosa MTCC 2453. Endophytic fungi isolated from agriculture field were evaluated for antibiofilm activity. After fermentation in sucrose broth, biofilm formation inhibitors from endophytic fungi were extracted using ethyl acetate. The active extract from each endophytic fungus was assayed for inhibition of biofilm formation using biosensor strain Pseudomonas aeruginosa. At highest tested concentration $(200 \mu \mathrm{g} / \mathrm{ml})$ of both fungal extract and biocidal agent, the extract from Fusarium sp.1 demonstrated maximum inhibition in biofilm formation (49.65\%) and minimum inhibition by Colletotrichum sp. extract $(18.21 \%)$ and inhibition was significant at $(\mathrm{P}<0.05)$. Similarly at highest tested concentration $(200 \mu \mathrm{g} / \mathrm{ml})$ of fungal extract alone, the maximum percent decrease $(18.90 \%)$ was observed in P. aeruginosa by Phoma sp. extract and minimum inhibition by Penicillium sp extract $(4.00 \%)$ with no statistical difference. On the other hand extract from Aspergillus sp.2 was found to show no antibiofilm activity but exhibit stimulatory effect on biofilm formation extract $(-4.78 \%)$. Combined effect of active fungal extract and biocidal agent resulted in significantly more percent biofilm inhibition as compared to fungal extract alone. The action of one or more active compounds extracted from endophytic fungi may be responsible for antibiofilm activity. Such compounds could be effective against emerging multidrug resistant pathogens.
\end{abstract}

Keywords- Endophytic fungi, Biofilm, Quorum sensing, Pseudomonas aeruginosa.

\section{INTRODUCTION}

Biofilm is a sticky, firm structure formed due to communal interaction of bacteria attached to substrate surface and submerged into extracellular slimy conglomerations [1], [2]. The process of attachment of biofilm to surfaces, a sequential process, where bacteria firstly are transported to living or nonliving surfaces and then adhere to it and formed microcolonies which then mature into aggregate in a hydrated polymeric matrix called Biofilms [3],[4],[5].

Biofilm forming bacteria are highly resistant to antimicrobial compounds, protecting themselves from negative impact of environment [6]. In addition to numerous chronic infections, biofilm also responsible for various infections of biomaterial used in medicine, such as catheters, medical devices and contact lenses [7]. Pseudomonas aeruginosa is Gram-negative bacterium and an increasingly prevalent opportunistic human pathogen, causing the majority of hospital infections and emerge as antibacterial drug resistant bacterium [8], [9], [10]. Certainly new alternatives to the currently available broad-spectrum antibiotics have to be developed, which should not kill the bacteria instead inhibit the pathogenicity of $P$. aeruginosa.

There is a group of fungi residing inside higher plants without causing any harm to them (endophytic fungi). Such plant endophytes being a large and mostly unexplored group require special attention for research as they have the special ability to safeguard its host against pathogens and herbivores with enormous number of varied bioactive compounds which have been produced by them. These varied bioactive compounds have potential therapeutic value leading to discovery of novel metabolites, and more specifically novel antibiotics. The novel bioactive metabolite extracted from Colletotrichum gloeosporioides serve as a possible origin of new antibiotics [11]. Plant endophytic fungi are microorganisms that colonize the inside of host healthy plant tissues, spending all or part of their lifecycle within the intercellular region of the plant parts, mostly in leaf, bark and root system typically causing no apparent disease symptoms [12], [13]. 
In comparison to any other endophytic microorganism group, the number of active compounds synthesized by endophytic fungi particularly is at greater extent. In the studies of Buatong et al. [14], the broadest antimicrobial spectrum was obtained against Gram-positive bacteria and narrow to mid range activity against Gram-negative bacteria by crude extracts from mangrove fungal endophytes [15]. A. J. Martín-Rodríguez et al. [16] reported the presence of potentially novel secondary metabolites extracted from marine endophytic fungi for QS inhibition in Chromobacterium violaceum CVO26.

There were limited reports available on antibiofilm activity of endophytic fungi and particularly endophytes isolated from agriculture field plant. Therefore present study was an attempt to screen endophytic fungi for the presence of active compounds against $P$. aeruginosa. The current study was aimed to assess the Anti-biofilm activity of endophytic fungi on quorum sensing controlled biofilm formation in $P$. aeruginosa tester strain.

\section{MATERIALS AND METHODS}

Endophytic fungi isolated from agriculture field used for the study were Aspergillus sp.1, Penicillium sp., Aspergillus sp., Pestalotiopsis sp., Trichoderma sp, Phomopsis sp., Fusarium sp.1, Colletotrichum sp., Fusarium sp.2 and Phoma sp.

\section{Quorum sensing inhibitors from endophytic fungi}

\section{Bacterial strains}

The bacterial strain used for QS inhibition assays was Pseudomonas aeruginosa MTCC 2453. The bacterial strain was stored in $40 \%$ glycerol stock at $-20^{\circ} \mathrm{C}$ and was cultured in Luria-Bertani (LB) broth prior to use.

\section{Liquid state Fermentation}

Sucrose broth $(50 \mathrm{ml})$ was prepared in a $250 \mathrm{ml}$ conical flask. All the isolated endophytic fungi was inoculated and then incubated at $30{ }^{\circ} \mathrm{C}$ for 24 hours. After incubation the same culture $(2 \% \mathrm{v} / \mathrm{v})$ transferred into $50 \mathrm{ml}$ sucrose broth and incubated at $30^{\circ} \mathrm{C}$ in an orbital shaker incubator at $140 \mathrm{rpm}$ for 5 days incubation [17].

\section{Extraction of quorum sensing inhibitors}

After fermentation, the cells were filtered using Whatman filter paper and the filtrate was extracted with an equal amount of ethyl acetate. Then, the concentration of organic phase was done by evaporation and the residue was dissolved in sterile Dimethyl Sulphoxide (DMSO) and kept in a deep freezer for further use [18].

\section{Biofilm inhibition assay using different extracts of the endophyte}

Biofilm inhibition assay of Pseudomonas aeruginosa MTCC 2453 was performed using various extracts of endophytic fungi. A 24 hours old culture of Pseudomonas aeruginosa was taken and diluted with LB broth in the ratio of 1:100 and incubated for another hour. The fungal extracts were prepared in nine (9) six-well lanes of a 96-well microtiter plate $(0,12.5,25,50,75,100$ and $200 \mu \mathrm{gm} / \mathrm{L}$ ) at $150 \mu \mathrm{L}$ each using LB broth as diluent and $50 \mu \mathrm{L}$ aliquots of culture were seeded into the wells of the microtiter plate and then the plate was given incubation for $48 \mathrm{hrs}$ at $37{ }^{\circ} \mathrm{C}$. Thereafter, culture medium was removed from the microtitre plate and the wells were washed with $200 \mu \mathrm{L}$ of Phosphate Buffer saline (PBS). PBS was removed and $1 \%$ (w/v) crystal violet $(\mathrm{CV})(100 \mu \mathrm{L})$ was added to stain the polysaccharides of the biofilm. Following staining at room temperature for $20 \mathrm{~min}$, the dye was removed. The wells were washed thoroughly with sterile water and drained upside down on paper towels. For quantification of attached cells the bound CV was solubilised in dimethyl sulfoxide (DMSO) and the plate was agitated on orbital shaker until colour is uniform. The OD of each well was determined at $570 \mathrm{~nm}$. A separate procedure was done to assess biofilm sensitivity to biocidal agents. The same process was repeated until the growth of biofilms but after discarding the medium and washing with distilled water, the wells was washed with $1 \%$ sodium dodecyl sulfate (SDS) to disrupt the biofilms that formed in the walls. The same steps for staining, washing and quantification were followed as mentioned above [19].

Culture with no added endophytic fungal extract with the media considered as control [20]. The percent of biofilm inhibition was evaluated using the following formula.

$\%$ of biofilm inhibition $=100 \times([$ Control OD570 $\mathrm{nm}-$ Test OD570 nm $] /$ Control OD570 nm $)$

\section{Statistical analysis}

All experiments were performed in three replicated and the data was presented as Mean (SD). The data were analyzed for statistical significance using analysis variance (One way ANOVA) by Tukey test using SPSS 20.0 and Microsoft excel 2007 to compare the treatment group with their respective controls. The results are significant at $\mathrm{P} \leq 0.05$. 


\section{RESULTS AND DISCUSSION}

\section{Antibiofilm activity of active fraction of different fungal extracts}

The in vitro biofilm inhibition activity of the active fraction was evaluated at their respective concentration range $(0,12.5,25$, 50,100 and $200 \mu \mathrm{g} / \mathrm{ml}$ ) against the test bacterial strain. The different extracts exhibited varying degree of inhibitory effect on bacterial biofilm formation and results are presented in Table 1. In fungal extract and Biocidal agent treatment and at highest tested concentration $(200 \mu \mathrm{g} / \mathrm{ml})$, the percent decrease in biofilm formation of Pseudomonas aeruginosa was ranged from 18.21 to 49.65 . The extract from Fusarium sp. 2 demonstrated maximum inhibition in biofilm formation (49.65\%), followed by Pestalotiopsis sp extract $(44.47 \%)>$ Phoma sp extract (39.61\%) > Aspergillus spl extract (39.37\%) > Fusarium sp.1 extract $(34.25 \%)>$ Trichoderma sp extract $(33.06 \%)>$ Penicillium sp extract $(26.65 \%)>$ Aspergillus sp2 extract $(24.08 \%)>$ Phomopsis sp extract (22.18\%) and minimum inhibition by Colletotrichum sp extract (18.21\%) (Figure1). Similar studies were done by Meenambiga and Rajagopal [20] in which various solvent extracts of fungal endophyte Aspergillus nidulans has good inhibitory activity on the biofilm forming Candida albicans strain. In present study, the inhibition was found to be concentration dependent and was significant at $(\mathrm{P}<0.05)$ except percentage value for Penicillium sp extract.

When only fungal extract treatment given, the percentage for inhibition of biofilm formation of test bacterial strain, at highest tested concentration $(200 \mu \mathrm{g} / \mathrm{ml})$ was ranged from 4.00 to 18.90 . The maximum percent decrease (18.90) was observed in Pseudomonas aeruginosa by Phoma sp extract, followed by Fusarium sp.2 extract (16.90\%) > Fusarium sp.1 extract (14.94\%) $>$ Aspergillus spl extract $(14.11 \%)>$ Phomopsis sp extract $(9.70 \%)>$ Pestalotiopsis sp extract $(8.63 \%)>$ Colletotrichum sp extract $(8.52 \%)>$ Trichoderma $s p$ extract $(7.19 \%)$ and minimum inhibition by F2 extract Penicillium sp. The results are presented in Table 2. Chari Nithya et al. [21] reported Chlamydomonas sp. extract have the potential for biofilm inhibition against P. aeruginosa PA14 and P. aeruginosa ATCC 10145. On the other hand extract from Aspergillus sp2 was found to show no antibiofilm activity but exhibiting stimulatory effect on biofilm formation extract ( $-4.78 \%)$. The inhibition was found to be concentration dependent and was significant at $(\mathrm{P}<0.05)$ except the percentage value obtained for extracts of Aspergillus sp1, Penicillium sp, Aspergillus sp1, Trichoderma sp and Phoma sp indicated no statistical difference (Figure2).

Table1. Effect of increasing concentration of different fungal extracts on biofilm formation by Pseudomonas aeruginosa (With Biocidal treatment)

\begin{tabular}{|c|c|c|c|c|c|c|c|c|c|c|}
\hline $\begin{array}{l}\text { Couceutrabion } \\
\text { of fungal } \\
\text { extract } \\
\text { (ug/ml) }\end{array}$ & Asperginusspl & Penicilliven sp. & Aspergillus sp.2 & Pestalotiopsissp. & Frichodermasp. & Phomonsissp. & Ensariumsp.l 1 & Colletatrichwesp. & Ensquivesp.2 & $\begin{array}{c}\text { Phoma } \\
\text { sp. }\end{array}$ \\
\hline 0 & $1.016 \pm 0.0471$ & $1.038=0.057$ & $1.01=0.013$ & $0.958=0.011$ & $0.906 \pm 0.025$ & $0.958 \pm 0.024$ & $1.001=0.008$ & $0.999=0.002$ & $1.001=0.02$ & $\begin{array}{c}1.021=0.0 \\
116\end{array}$ \\
\hline 125 & $\begin{array}{c}0.944 \pm 0.0110 \\
(7.12)\end{array}$ & $\begin{array}{c}0.984 \pm 0.008 \\
(523)\end{array}$ & $\begin{array}{c}0.99 \pm 0.018 \\
(2.04)\end{array}$ & $\begin{array}{c}0.955 \pm 0.019 \\
(0.31)\end{array}$ & $\begin{array}{c}0.906 \pm 0.016 \\
(0.06)\end{array}$ & $\begin{array}{c}0.954 \pm 0.026 \\
(0.40)\end{array}$ & $\begin{array}{c}0.972 \pm 0.018 \\
(3.07)\end{array}$ & $\begin{array}{c}0.991=0.003 \\
(0.80)\end{array}$ & $0.96 \pm 0.018(4.10)$ & $\begin{array}{l}0.979 \pm 00 \\
114(4.05)\end{array}$ \\
\hline 25 & $\begin{array}{c}0.835 \pm 0.0152 \\
(175)^{4}\end{array}$ & $\begin{array}{c}0.972=0.008 \\
(6.32)\end{array}$ & $0.981=0.013(294)$ & $\begin{array}{c}0.904 \pm 0.004 \\
(5.60)\end{array}$ & $\begin{array}{c}0.88=0.036 \\
(2.87)\end{array}$ & $\begin{array}{c}0.924 \pm 0.011 \\
(3.53)\end{array}$ & $\begin{array}{c}0.933 \pm 0.016 \\
(7.51)\end{array}$ & $\begin{array}{c}0.975 \pm 0.009 \\
(2.40)\end{array}$ & $\begin{array}{c}0.875 \pm 0.02 \\
(12.02)\end{array}$ & $\begin{array}{c}0.916 \pm 00 \\
129 \\
(10.22)\end{array}$ \\
\hline 50 & $\begin{array}{c}0.738 \pm 0.027 \\
(27.40)\end{array}$ & $\begin{array}{c}0.861=0.019 \\
(17.05)\end{array}$ & $0.981=0.004(294)$ & $\begin{array}{c}0.858 \pm 0.012 \\
(10.40)\end{array}$ & $\begin{array}{c}0.868=0.015 \\
(421)\end{array}$ & $\begin{array}{c}0.909 \pm 0.009 \\
(5.13)\end{array}$ & $\begin{array}{c}0.895 \pm 0.01 \\
(11.35)\end{array}$ & $\begin{array}{c}0.92 \pm 0.029 \\
(7.89)\end{array}$ & $\begin{array}{c}0.828 \pm 0.014 \\
(1728)\end{array}$ & $\begin{array}{c}0.845 \pm 0.0 \\
344 \\
(1721)\end{array}$ \\
\hline 100 & $\begin{array}{c}0.095 \pm 0.038 \\
(31.59)\end{array}$ & $\begin{array}{c}0.838=0.026 \\
(1923)\end{array}$ & $\begin{array}{c}0.908 \pm 0.008 \\
(10.13)^{4}\end{array}$ & $\begin{array}{l}0.74 \pm 0.032 \\
(22.69)^{4+4}\end{array}$ & $\begin{array}{c}0.802 \pm 0.011 \\
(11.53)^{4}\end{array}$ & $\begin{array}{c}0.858 \pm 0.004 \\
(10.42)^{4}\end{array}$ & $\begin{array}{l}0.823 \pm 0.036 \\
(1850)^{4}\end{array}$ & $\begin{array}{c}0.889=0.019 \\
(10.98)\end{array}$ & $\begin{array}{l}0.749=0.016 \\
(2521)^{4}+4\end{array}$ & $\begin{array}{l}0.813 \pm 0.0 \\
06(20.31)\end{array}$ \\
\hline 200 & $\begin{array}{c}0.016 \pm 0.016 \\
(39.37)^{4}\end{array}$ & $\begin{array}{c}0.761 \pm 0.033 \\
(26.65)\end{array}$ & $\begin{array}{l}0.767 \pm 0.028 \\
(24.08)^{4}+4\end{array}$ & $\begin{array}{l}0.532 \pm 0.014 \\
(44.47)+4\end{array}$ & $\begin{array}{l}0.607 \pm 0.01 \\
(33.06)^{4+4}\end{array}$ & $\begin{array}{l}0.745 \pm 0.005 \\
(22.18)^{4}+4\end{array}$ & $\begin{array}{c}0.664 \pm 0.034 \\
(3425)^{4}+4\end{array}$ & $\begin{array}{l}0.817 \pm 0.028 \\
(1821)^{404}\end{array}$ & $\begin{array}{l}0.504 \pm 0.03 \\
(49.65)^{* t *}\end{array}$ & $\begin{array}{c}0.616 \pm 00 \\
59 \\
(39.61)^{44}\end{array}$ \\
\hline
\end{tabular}

Biofilm formation is expressed as OD 570 after incubation with crystal violet.

The data represent mean value of three independent experiments. *significance at $P=0.05, * *$ significance at $P=0.01, * * *$ significance at $P=0.005$.

The value in parenthesis represents percent reduction over control. 


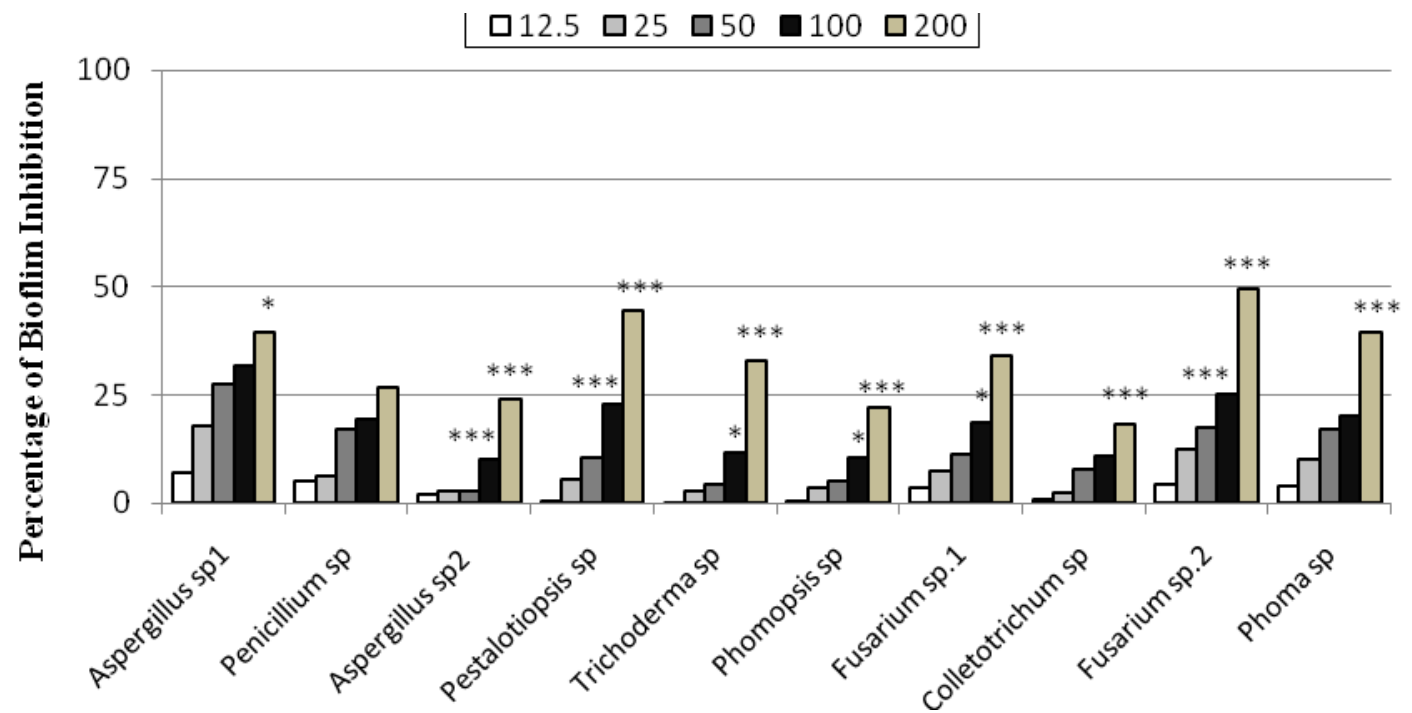

Figure1. Effect of concentration $(0-200 \mu \mathrm{g} / \mathrm{ml})$ of different fungal extracts on biofilm formation by Pseudomonas aeruginosa (With Biocidal treatment)

Table2. Effect of increasing concentration of different fungal extracts on biofilm formation by Pseudomonas aeruginosa (Without Biocidal treatment)

\begin{tabular}{|c|c|c|c|c|c|c|c|c|c|c|}
\hline $\begin{array}{l}\text { Coucentrat } \\
\text { ion } \\
\text { of fungal } \\
\text { extract } \\
\text { (ug/ml) }\end{array}$ & Aspergiñusp:1 & $\begin{array}{c}\text { Penicilinum s } \\
p\end{array}$ & AsRersinusps? & Pestalotiopsis.sp & Irichoderma sp & Phomogsis sp & Ensquivonsp.1 1 & Colletotrichum sp & Evariwomsp.2 & $\begin{array}{c}\text { Phoma } \\
\text { sp }\end{array}$ \\
\hline 0 & $0.95=0.03$ & $0.934=0.041$ & $0.962 \pm 0.025$ & $0.989=0.011$ & $0.853 \pm 0.034$ & $0.869=0.011$ & $0.996=0.006$ & $0.982=0.004$ & $0.937 \pm 0.0276$ & $\begin{array}{c}096=0 . \\
03\end{array}$ \\
\hline 125 & $\begin{array}{c}0.935 \pm 0.018 \\
(1.58)\end{array}$ & $\begin{array}{c}0.965=0.029 \\
(-332)\end{array}$ & $\begin{array}{c}0.968 \pm 0.021 \\
(-0.59)\end{array}$ & $\begin{array}{c}0.997 \pm 0.007 \\
0.77)\end{array}$ & $\begin{array}{c}0.851=0.02 \\
(0.27)\end{array}$ & $\begin{array}{c}0.865=0.006 \\
(0.44)\end{array}$ & $1 \pm 0.002$ & $\begin{array}{r}0.989 \pm 0.007 \\
0.64)\end{array}$ & $\begin{array}{c}0.935 \pm 0.039 \\
(0.18)\end{array}$ & $\begin{array}{c}0.969=0 \\
04 \\
(-0.97)\end{array}$ \\
\hline 25 & $\begin{array}{c}0.881 \pm 0.03 \\
(723)\end{array}$ & $\begin{array}{c}0.95=0.025 \\
(-1.71)\end{array}$ & $\begin{array}{c}0.992 \pm 0.009 \\
(-3.08)\end{array}$ & $0.989 \pm 0.022(0.07)$ & $\begin{array}{c}0.838 \pm 0.053 \\
(1.80)\end{array}$ & $\begin{array}{c}0.861=0.003 \\
(0.92)\end{array}$ & $\begin{array}{c}0.984 \pm 0.004 \\
(1.20)\end{array}$ & $0.979 \pm 0.009(0.31)$ & $\begin{array}{c}0.924 \pm 0.045 \\
(1.35)\end{array}$ & $\begin{array}{l}0.963=0 \\
02(- \\
0.31)\end{array}$ \\
\hline 50 & $\begin{array}{c}0.853 \pm 0.021 \\
(10.18)\end{array}$ & $\begin{array}{c}0.949 \pm 0.013 \\
(-1.64)\end{array}$ & $\begin{array}{c}0.993 \pm 0.021 \\
(-3.19)\end{array}$ & $0.985 \pm 0.015(0.44)$ & $\begin{array}{c}0.823 \pm 0.01 \\
(3.59)\end{array}$ & $\begin{array}{c}0.851 \pm 0.006 \\
(2.11)\end{array}$ & $\begin{array}{c}0.975 \pm 0.003 \\
(2.14)\end{array}$ & $0.969 \pm 0.002(1.41)$ & $\begin{array}{c}0.905 \pm 0.026 \\
(3.42)\end{array}$ & $\begin{array}{l}0.934=0 \\
056 \\
(2.67)\end{array}$ \\
\hline 100 & $\begin{array}{c}0.83 \pm 0.012 \\
(12.60)\end{array}$ & $\begin{array}{c}0.925=0.015 \\
(0.93)\end{array}$ & $\begin{array}{c}1.001=0.009 \\
(-4.05)\end{array}$ & $0.96 \pm 0.02 \quad(2.93)$ & $\begin{array}{c}0.812=0.003 \\
(4.88)\end{array}$ & $\begin{array}{c}0.835 \pm 0.012 \\
(3.87)\end{array}$ & $\begin{array}{c}0.898 \pm 0.003 \\
(9.82)^{44}\end{array}$ & $0.959=0.002(2.43)$ & $\begin{array}{c}0.871=0.023 \\
(7.01)\end{array}$ & $\begin{array}{l}0.88=0 . \\
03 \\
(830)\end{array}$ \\
\hline 200 & $\begin{array}{c}0.816 \pm 0.016 \\
(14.11)\end{array}$ & $\begin{array}{c}0.897 \pm 0.011 \\
(4.00)\end{array}$ & $\begin{array}{c}1.008 \pm 0.006 \\
(4.78)\end{array}$ & $\begin{array}{c}0.904 \pm 0.016 \\
(8.63)^{44}\end{array}$ & $\begin{array}{c}0.792 \pm 0.011 \\
(7.19)\end{array}$ & $\begin{array}{l}0.785 \pm 0.009 \\
(9.70)^{44}\end{array}$ & $\begin{array}{c}0.847 \pm 0.036 \\
(1494)^{44}\end{array}$ & $\begin{array}{c}0.899 \pm 0.007 \\
(8.52) 44\end{array}$ & $\begin{array}{c}0.779 \pm 0.012 \\
(1690)^{4}\end{array}$ & $\begin{array}{l}0.778=0 \\
016 \\
(18.90)\end{array}$ \\
\hline
\end{tabular}

Biofilm formation is expressed as OD 570 after incubation with crystal violet.

The data represent mean value of three independent experiments. *significance at $P=0.05$, ** significance at $P=0.01$, *** significance at $P=0.005$.

The value in parenthesis represents percent reduction over control. 


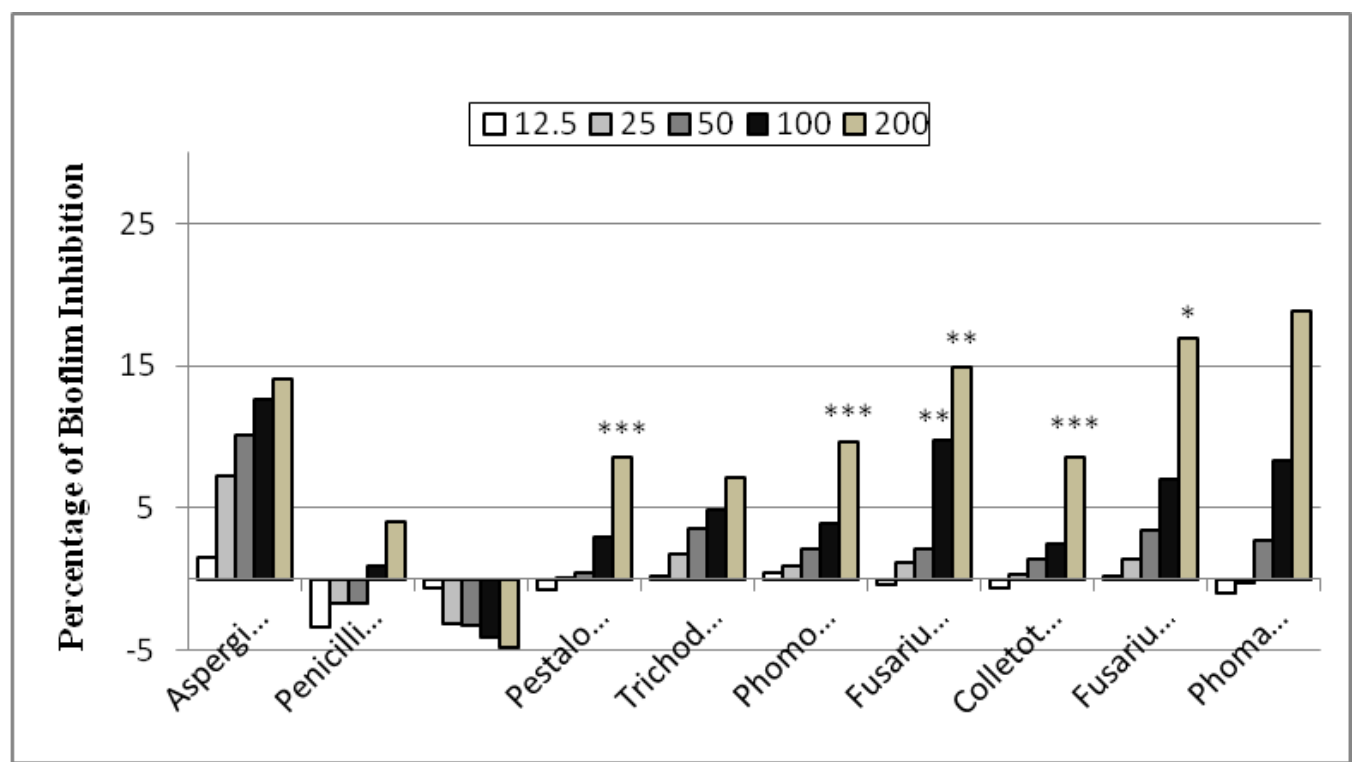

Figure2. Effect of concentration $(0-200 \mu \mathrm{g} / \mathrm{ml})$ of different fungal extracts on biofilm formation by Pseudomonas aeruginosa (Without Biocidal treatment)

\section{CONCLUSION}

In this investigation, the aim was to evaluate potential of endophytic fungi to inhibit biofilm formation by $P$. Aeruginosa. This study has identified maximum anti-biofilm activity by combined effect of Fusarium sp.1 and biocidal agent whereas fungal extract of Phoma sp. alone also showed maximum anti-biofilm activity. These findings suggest that, in general, the inhibition of production of QS linked virulence factor i.e. biofilm in $P$. aeruginosa tester strain. This has clearly demonstrated broad spectrum anti-QS role of extracts in pathogenic bacterium. Compared to combined effect, effect of the fungal extract alone demonstrated significantly less percent inhibition in biofilm formation. Further studies on purification and identification of active compound(s) need to be carried out in order to validate efficacy of fungal extract. Antibiofilm activity of fungal extracts may be attributed to the action of active compounds or cumulative effect of more than one constituent. The presence of such active compounds is always being an added advantage for chemotherapeutic efficacy of bioactive extracts. Use of such compounds could be one of the treatment tools against emerging multidrug resistant pathogens.

\section{ACKNOWLEDGMENT}

Authors duly acknowledge the Principal, Teaching \& Non-Teaching staff of Taywade College, Koradi, Nagpur, Maharashtra, India.

\section{CONFLICT OF INTEREST}

There is no any conflict of interest exist.

\section{REFERENCES}

[1] C. Potera, "Forging a Link Between Biofilms and Disease," Science. vol. 283: 1837-1839, 1999.

[2] M. S. P. B. D and S. Yadav, "Biofilms : Microbes and Disease," Brazilian Journal of Infectious Diseases vol, 12, pp. 526-530, 2008

[3] J. W. Costerton, P. S. Stewart, and E. P. Greenberg, "Bacterial Biofilms : A Common Cause of Persistent Infections," Science, vol. 284, no. May, pp. 1318-1322, 1999.

[4] T. I. M. Tolker-nielsen, U. C. Brinch, P. C. Ragas, J. B. O. Andersen, C. S. Jacobsen, and S. Molin, "Development and Dynamics of Pseudomonas sp, Biofilms," Journal of Bacteriology, vol. 182, no. 22, pp. 6482-6489, 2000.

[5] K. Sauer et al., "Pseudomonas aeruginosa Displays Multiple Phenotypes during Development as a Biofilm Pseudomonas aeruginosa Displays Multiple Phenotypes during Development as a Biofilm,", Journal of Bacteriology, 184:1140-54. 2002.

[6] M. G. Kociolek, "Quorum-Sensing Inhibitors and Biofilms," Journal of Medicinal Chemistry, vol. 8, no.4, pp. 315-326, 2009.

[7] W. Yao, D. A. I. Yue, Z. Yong, H. U. Yangbo, Y. Baoyu, and C. Shiyun, "Effects of quorum sensing autoinducer degradation gene on virulence and biofilm formation of Pseudomonas aeruginosa," Science in China Series C Life Sciences, vol. 50, no. $30570020,2007$. 
[8] C. Van Delden and B. H. Iglewski, “Cell-to-Cell Signaling and Pseudomonas aeruginosa Infections,” Emerging Infectious Dieasess. vol. 4, no. 4, pp. 551-560, 1998.

[9] L. B. Rice, "Federal Funding for the Study of Antimicrobial Resistance in Nosocomial Pathogens : No ESKAPE," The Journal of Infectious Diseases, vol. 197, pp. 1079-1081, 2008.

[10] Macé, C, D. Seyer, C. Chemani, P. Cosette, P. Di-Martino et al., "Identification of Biofilm-Associated Cluster ( bac ) in Pseudomonas aeruginosa Involved in Biofilm Formation and Virulence," PLOS.vol. 3, no. 12, pp. 1-10, 2008.

[11] U. S. E. Arivudainambi, T. D. Anand, V. Shanmugaiah, C. Karunakaran, and A. Rajendran, "Novel Bioactive metabolites producing endophytic fungus Colletotrichum gloeosporioides against multidrug-resistant Staphylococcus aureus," FEMS Immunology \& Medical Microbiology, vol. 61, pp. 340-345, 2011.

[12] R. X. Tan and W. X. Zou, "Endophytes : a rich source of functional metabolites," Natural Products Reports, no. 18, pp. 448-459, 2001.

[13] W. X. Zou et al., "Metabolites of Colletotrichum gloeosporioides , an Endophytic Fungus in Artemisia mongolica," Journal of Natural Products, vol. 63, no. 11. 1529-1530, 2000.

[14] J. Buatong and S. Phongpaichit, "Antimicrobial activity of crude extracts from mangrove fungal endophytes," World Journal Microbiology and Biotechnology no. 27 pp. 3005-3008, 2011.

[15] N. Radic and B. Strukelj, "Phytomedicine Endophytic fungi -The treasure chest of antibacterial substances," Phytomedicine vol. 19, pp. 1270$1284,2012$.

[16] A. J. Martín-Rodríguez et. al., “Aquatic Fungi : First Report from Marine Endophytes,” Marine Drugs, no.12, pp. 5503-5526, 2014.

[17] P. S. Rajesh and V. R. Rai, "Biocatalysis and Agricultural Biotechnology Hydrolytic enzymes and quorum sensing inhibitors from endophytic fungi of Ventilago madraspatana Gaertn," Biocatalysis Agricultural Biotechnology., vol. 2, no. 2, pp. 120-124, 2013.

[18] M. Ueda, T. Kubo, and K. Miyatake, "Purification and characterization of fibrinolytic alkaline protease from Fusarium sp . BLB," Applied Microbiology and Biotechnology, vol. 74 pp. 331-338, 2007.

[19] J. C. Taganna, J. P. Quanico, R. Marie, G. Perono, E. C. Amor, and W. L. Rivera, "Tannin-rich fraction from Terminalia catappa inhibits quorum sensing ( QS ) in Chromobacterium violaceum and the QS-controlled biofilm maturation and LasA staphylolytic activity in Pseudomonas aeruginosa," Journal of Ethnopharmacology, vol. 134, pp. 865-871, 2011.

[20] S. S. Meenambiga and K. Rajagopal, "Antibiofilm activity and molecular docking studies of bioactive secondary metabolites from endophytic fungus Aspergillus nidulans on oral Candida albicans," Journal of Applied Pharmaceutical Science, vol. 8, no. 3, pp. 37-45, 2018.

[21] C. Nithya, F. Lewisoscar, S. Kanaga, R. Kavitha, and D. Bakkiyaraj, "Biofilm inhibitory potential of Chlamydomonas sp. extract against Pseudomonas aeruginosa," Journal of Algal Biomass Utilization, vol. 5, no. 4, pp. 74-81, 2014. 